\title{
The Statistical Value of Injury Risk in Pakistan's Construction and Manufacturing Sectors
}

\author{
Ahmad Mujtaba Khan* and Asma Hyder**
}

\begin{abstract}
Although health and safety regulations are a key aspect of labor market policymaking, very few studies have examined compensating wage differentials and the statistical value of injury in Pakistan's context. This study looks at injury risk against occupation and industry, using data from the Labor Force Survey for 2013/14. We target five blue-collar occupations in two industries (construction and manufacturing), which tend to account for the highest number of injuries. However, we find that the statistical value of injury in these occupations is too small to reflect the wage premium that workers should be paid for risky jobs.
\end{abstract}

Keywords: value of injury, industry, labor market conditions, public policy, Pakistan.

\section{JEL classification: $\mathrm{O} 14$.}

\section{Introduction}

With a population of approximately 182.1 million (United Nations Population Fund, 2013), Pakistan's total workforce comprises 59.74 million, of which 45.98 million are male and 13.76 million are female (Labor Force Survey for 2012/13). The country ranks 146th out of 187 countries on the 2014 Human Development Index: most of its indicators are below those of other South Asian countries and it has failed to meet several targets under the Millennium Development Goals. In 2013, public spending on education was 2.1 percent of GDP, indicating that education remains a low priority. Similarly, public health expenditure was merely 1 percent of GDP in 2013, making Pakistan one of the world's lowest spenders under this head (World Bank, 2014).

The literature on labor economics uses three different approaches to estimate the statistical value of injury (SVI) or life. The first, developed by Viscusi and Aldy (2003), suggests that workers be compensated for risky

\footnotetext{
* Research Officer, Value Resources Private Limited, Islamabad, Pakistan.

** Associate Professor, Institute of Business Administration, Karachi, Pakistan.
} 
jobs in the form of wages. The second approach, put forward by Blomquist (2004), entails observing the behavior of workers prepared to undertake risk and measuring its cost. The third is the willingness-to-pay approach, according to which workers are asked how much they are willing to pay to reduce the fatal or nonfatal risk associated with their jobs. This study uses the first approach to estimate a wage-risk premium for workers in Pakistan's manufacturing and construction sectors.

\section{Literature Review}

Insufficient wage and labor data for developing countries has meant that the literature in this area is scant. The theory of compensating wage differentials itself goes back to Adam Smith, who observed that workers required compensation in the form of higher wages to accept any fatal or nonfatal risk associated with a job. Thaler and Rosen (1976) develop a hedonic wage function that measures the wage-risk tradeoff or wage differential associated with fatal and nonfatal job risk. Schelling (1968) gauges the extent to which workers are willing to accept risk in the process of labor market bargaining over the composition and acceptance or prevention of such risk.

Among more recent studies, Viscusi and Aldy (2003) estimate the value of life by constructing a fatality risk variable based on data for a range of occupations and industries. Using a hedonic wage equation, they find that the value of life is US $\$ 4.7$ million across the sample, and is US $\$ 7.0$ million and US\$8.5 million for blue-collar male and female workers, respectively. Kluve and Schaffner (2007) examine the impact of compensation for injury risk on the gender pay gap. Finding that male workers are far more likely to be exposed to riskier jobs than female workers, they calculate the observed gender pay gap resulting from job segregation into those that are more dangerous or less so.

Hammitt and Ibarrarán (2006) use compensating wage differentials to estimate the tradeoff between occupational injury risk and income in Mexico City. Their survey provides data on fatal and nonfatal occupational injury risk for a sample of 600 workers, in addition to which they rely on government statistics for actuarial risk data. While the results obtained from the variables that represent workers' subjective perception of risk (based on the survey) may be less reliable, the estimates obtained using the actuarial risk variables are more accurate, given their insensitivity to the omitted variable problem. The values estimated for injury risk are smaller than those for developed countries such as the US, but closer to higher- 
income countries such as Taiwan and Korea. The results of such studies can be used in cost-benefit analyses to mitigate health and environmental risks in the workplace.

The literature includes a number of studies on compensating wage differentials in labor markets: see, for example, Atkinson and Halvorsen (1990); Shanmugam (2000) and Madheswaran (2004) for India; Liu and Hammitt (1999) for Taiwan; Parada-Contzen, Riquelme-Won and VasquezLavin (2013) for Chile; Polat (2013) for Turkey; and Rafiq and Shah (2010) and Hyder and Behrman (2011) for Pakistan (Table A1 in the Appendix summarizes the literature review). This paper contributes to the literature from a developing country perspective by looking at two different types of risk: the occupational injury risk rate and the industrial injury risk rate. Using both measures provides a broader comparative picture of the SVI in Pakistan's labor market.

\section{Data and Summary Statistics}

We use data from the Labor Force Survey for 2012/13, drawing on a sample of 6,421 individuals. It is worth noting that the survey has certain limitations: (i) its categorization of occupations and industries restricts the study to 2-digit industries; and (ii) it does not provide any information on the nature of injuries or the number of fatalities, which means that we cannot estimate the cost associated with a particular kind of injury. As a result, the study is restricted to nonfatal risk for which one would expect labor market compensation. Thus, for our purposes, any worker who reported an injury that was followed by a medical consultation is considered a workplace injury.

The hedonic wage equation we estimate takes the log of the hourly wage as a dependent variable. The independent variables include injury risk or nonfatal injury per 100 workers (both industrial and occupational risk), job training, the type of job (permanent or temporary), a regional dummy (urban, rural), provincial dummies, a sector dummy (private, public), human capital variables (age, age-squared and level of education) and two industrial and broad occupational categories. Table 1 presents the study's summary statistics.

The sample includes people of working age, that is, 14-65 years, where age is a proxy for labor market experience is expected to have a positive effect on wages. Age-squared is expected to have a negative sign because it shows how the impact of experience changes over time. While 
some studies use the Mincer proxy (a school-going age of six years), this does not apply in Pakistan's case where there is no fixed school-going age. Moreover, the high unemployment rate means that not every individual is guaranteed employment after leaving school.

Table 1: Summary statistics

\begin{tabular}{|c|c|}
\hline Variable & Percentage \\
\hline \multicolumn{2}{|l|}{ Gender } \\
\hline Male & 93 \\
\hline Female & 7 \\
\hline \multicolumn{2}{|l|}{ Training } \\
\hline Trained & 26 \\
\hline Not trained & 74 \\
\hline \multicolumn{2}{|l|}{ Education } \\
\hline No formal schooling & 55 \\
\hline Primary to middle & 32 \\
\hline Matriculation & 8 \\
\hline Higher & 5 \\
\hline \multicolumn{2}{|l|}{ Province } \\
\hline Punjab & 19 \\
\hline Sindh & 47 \\
\hline $\mathrm{KP}$ & 26 \\
\hline Balochistan & 8 \\
\hline \multicolumn{2}{|l|}{ Region } \\
\hline Rural & 56 \\
\hline Urban & 44 \\
\hline \multicolumn{2}{|l|}{ Industry } \\
\hline Manufacturing & 34 \\
\hline Construction & 66 \\
\hline \multicolumn{2}{|l|}{ Job status } \\
\hline Permanent & 14 \\
\hline Contractual & 61 \\
\hline Without contract & 25 \\
\hline \multicolumn{2}{|l|}{ Occupation } \\
\hline Services and market sales & 5 \\
\hline Craft and related trades & 37 \\
\hline Plant and machine operation & 7 \\
\hline Assembly (elementary occupations) & 51 \\
\hline
\end{tabular}

Source: Authors' calculations based on data from the Labor Force Survey for 2012/13. 
The education variable is divided into five categories: (i) no formal education, (ii) primary schooling but below middle school, (iii) middle schooling but below matriculation, (iv) schooling up to and including matriculation and (v) education beyond matriculation. Technical training is expected to have a positive sign because it is associated with higher wages (75 percent of the workers in our sample had no formal job training). The province variable gauges the wage differential for each of the four provinces. Of the total sample of workers, 19 percent are from Punjab, 48 percent from Sindh, 26 percent from Khyber Pakhtunkhwa (KP) and 8 percent from Balochistan. In addition, the model includes job-related characteristics such as employment sector and the type of job held.

To enable a more detailed analysis, we include the occupational and industrial injury rates and associated demographics. As Table 2 shows, the occupational injury variable has a very high standard deviation because the severity of risk varies widely by occupation: those such as firefighting, kiln work and mining, for example, carry a higher risk than others. However, there may be less variation in the injury rate because a given industry will comprise numerous occupations, thus lowering the deviation of risk.

Table 2: Occupational injury rate, by industry

\begin{tabular}{lcc}
\hline Variable & Mean & Standard deviation \\
\hline Injury rate in industry & 6.00 & 2.34 \\
Injury rate in occupation & 5.93 & 5.90 \\
\hline
\end{tabular}

Note: Per 100 workers.

Source: Authors' calculations based on data from the Labor Force Survey for 2012/13.

Table 3 shows that men are exposed to greater risk of injury in the labor market than women, who tend to be more risk-averse and less likely to opt for high-risk, physically demanding occupations.

Table 3: Average industrial injury rate, by gender

\begin{tabular}{lcc}
\hline Gender & Injury rate by industry & Injury rate by occupation \\
\hline Male & 6.21 & 6.08 \\
Female & 2.64 & 3.80 \\
\hline
\end{tabular}

Note: Per 100 workers.

Source: Authors' calculations based on data from the Labor Force Survey for 2012/13. 


\section{Construction of Injury Rate Variables}

The hedonic wage equation includes an industrial injury risk variable that is calculated using the formula adopted by the US Bureau of Labor Statistics:

\section{Industrial injury rate $=\mathrm{N} / \mathrm{H} \times 200,000$}

where $\mathrm{N}$ is the total number of injuries to have occurred in a given industry ${ }^{1}$ and $\mathrm{H}$ is the total number of hours worked by all employees in that industry in a year. The figure 200,000 is a combined base scaling the total number of hours worked by 100 workers in a year - a technique also used by Hersch (1998). Table A2 in the Appendix lists the 2-digit industries covered by the study.

The same method is used to calculate the occupational injury rate:

\section{Occupational injury rate $=\mathrm{N} / \mathrm{H} \times 200,000$}

where $\mathrm{N}$ is the total number of injuries to have occurred in a given occupation and $\mathrm{H}$ is the total number of hours worked by all employees in that occupation in a year. Again, 200,000 is a combined base scaling the total number of hours worked by 100 workers in a year. Table A3 in the Appendix lists the blue-collar occupations covered by the study.

\section{Theoretical Model}

Under the hedonic wage model, the demand for labor is a decreasing function of the cost of employing labor, i.e., as the cost of employing a worker rises, the demand for his or her labor falls. This cost includes salary and compensation as well as the cost of providing medical care, training and a safe working environment. For a given level of profit, firms will pay their workers less as these costs increase. Thus, workers will choose a wage-risk combination that yields the highest wage.

The hedonic wage function we employ is adapted from the models developed by Viscusi (2003) and Elia, Carrieri and Di Porto (2009). We assume that risk has a price in the form of a wage premium, such that workers are willing to reduce the probability of injury or death by forgoing part of this wage premium. Thus, firms and workers set a wage-risk combination $(w, r)$ in the implicit labor market.

\footnotetext{
${ }^{1}$ The survey asks respondents if, in the last 12 months, they have suffered any occupational injury or disease that led them to take time off work and/or consult a doctor.
} 
We also assume that a worker's decision to work in a certain occupation or industry depends solely on the associated risk and wage rate. Let $U(w)$ denote the utility function of a healthy worker and $V(w)$ the utility function of a nonhealthy or injured worker at wage $w$. Assuming that a worker would rather be healthy than injured, $U(w)>V(w)$. In both cases, the marginal utility of the wage rate is positive: $U^{\prime}(w)>0, V^{\prime}(w)>0$.

If $f$ is the likelihood of an accident (nonfatal), then the expected utility function of a worker will be:

$$
Q=(1-f) U(w)+f V(w)
$$

Differentiating equation (1) with respect to $f$ and $w$, we obtain the wage-risk tradeoff:

$$
\frac{d w}{d f}=-\frac{Q_{f}}{Q_{w}}=\frac{\mathrm{U}(\mathrm{w})-V(w)}{(1-f) U^{\prime}(w)+f V^{\prime}(w)}>0
$$

Equation (2) shows that, as the level of risk increases, so does the wage rate - this is the compensating wage differential. The wage-risk tradeoff is, therefore, obtained by differentiating both utilities with respect to the marginal utility of wages.

\section{Empirical Model}

To calculate the SVI, we estimate the hedonic wage equation by regressing the log of the hourly wage on the model's independent variables - province, region, age, education, experience, industrial and occupational dummies and injury risk - using a semi-log linear model:

lnwage $=f$ (human capital variables and individual characteristics, residential characteristics, job characteristics, injury rate)

Equation (3) is estimated twice, ${ }^{2}$ first using the occupational injury rate and then the industrial injury rate. The log of hourly wages is constructed by dividing the weekly wage of the $i$ th worker by the total number of hours he/she has worked that week. ${ }^{3}$ The SVI is then calculated as follows:

\footnotetext{
${ }^{2}$ While computing this specification without the log of hourly wages yields similar results, the F-test statistics clearly support the use of lnwage. It also normalizes the distribution.

${ }^{3}$ In using this model, one concern is that workers do not select jobs at random and their preferences are unobserved. The literature on the statistical value of life or injury does not address this problem of selfselection per se. The most common method used is the Heckman two-stage procedure, which involves a discrete choice variable. Some studies employ union membership as the discrete choice variable at the
} 


$$
S V I=\beta * \bar{\omega} * 2,000 * 100
$$

where $\beta$ is the coefficient of the injury risk variable and $\bar{\omega}$ is the mean wage of all workers multiplied by 2,000 (as the total number of hours worked in a year to annualize the value) and then multiplied by 100 as the scale of the variable (per 100 workers). ${ }^{4}$

\section{Results and Discussion}

Table 4 gives the estimates obtained from the two hedonic wage equations specified earlier. In the first model, the injury risk variable is based on the 2-digit industry injury rate. The second model includes the 2digit occupation injury rate besides other control variables. Both sets of results exhibit a parabolic age-earning profile. Male workers receive higher wages than their female counterparts. The training variable is significant and negative and shows that workers without job training are paid 12 percent less than trained workers. ${ }^{5}$ The education category estimates are in line with human capital theory.

\section{Table 4: Regression results for two hedonic wage equations}

\begin{tabular}{lccc} 
& \multicolumn{2}{c}{ Dependent variable $=$ log of hourly wages } \\
\hline Independent variables & Model 1 & Model 2 & Model 3 \\
\hline Industrial injury rate & 0.006 & - & \\
& $(0.005)$ & & -0.043 \\
Occupational injury rate & - & $0.023^{* * *}$ & $(0.038)$ \\
& & $(0.006)$ & $0.006^{* *}$ \\
Occupational injury rate squared & & & $(0.0028)$ \\
& & & $0.0180^{* * *}$ \\
Controls & & & $(0.0039)$ \\
Age & $0.190^{* * *}$ & $0.190^{* * *}$ & $-0.0002^{* * *}$ \\
Age squared & $(0.004)$ & $(0.004)$ & $(0.00005)$ \\
& $-0.0002^{* * *}$ & $-0.0002^{* *}$ & $(0.00005)$ \\
Gender (ref. = male) & $(0.00005)$ & & $-0.303^{* * *}$ \\
Female & & $-0.310^{* * *}$ & $(0.037)$ \\
Training (ref. = trained) & $-0.326^{* * *}$ & $(0.038)$ & \\
\hline
\end{tabular}

first stage - see, for example, Marin and Psacharopoulos (1982) - but we are restricted to very limited choice variables as the Labor Force Survey does not provide any data on union membership.

4 2,000 is the annual average number of hours worked, used globally (see Viscusi, 2003).

${ }_{5}$ All the dummy coefficients are calculated by the following formula $100\left(e^{\text {coefficient }}-1\right)($ see Halvorsen \& Palmquist, 1980). 


\begin{tabular}{|c|c|c|c|}
\hline Independent variables & Model 1 & Model 2 & Model 3 \\
\hline Untrained & $\begin{array}{c}-0.115^{* * *} \\
(0.022)\end{array}$ & $\begin{array}{c}-0.120^{* * *} \\
(0.022)\end{array}$ & $\begin{array}{c}-0.131^{* * *} \\
(0.021)\end{array}$ \\
\hline \multicolumn{4}{|l|}{ Education (ref. = no schooling) } \\
\hline Primary to middle & $\begin{array}{c}0.062^{* * *} \\
(0.016)\end{array}$ & $\begin{array}{c}0.064^{* * *} \\
(0.016)\end{array}$ & $\begin{array}{l}-0.016 \\
(0.017)\end{array}$ \\
\hline Matriculation & $\begin{array}{l}0.053^{* *} \\
(0.026)\end{array}$ & $\begin{array}{l}0.052^{* *} \\
(0.027)\end{array}$ & $\begin{array}{c}0.216^{* * *} \\
(0.027)\end{array}$ \\
\hline Above matriculation & $\begin{array}{l}0.059^{*} \\
(0.032)\end{array}$ & $\begin{array}{l}0.058^{*} \\
(0.032)\end{array}$ & $\begin{array}{l}0.054^{* *} \\
(0.021)\end{array}$ \\
\hline \multicolumn{4}{|l|}{ Province (ref. = Punjab) } \\
\hline Sindh & $\begin{array}{c}-0.153^{* * *} \\
(0.017)\end{array}$ & $\begin{array}{c}-0.155^{* * *} \\
(0.017)\end{array}$ & $\begin{array}{c}-0.150^{* * *} \\
(0.016)\end{array}$ \\
\hline $\mathrm{KP}$ & $\begin{array}{c}-0.362^{* * *} \\
(0.023)\end{array}$ & $\begin{array}{c}-0.362^{* * *} \\
(0.024)\end{array}$ & $\begin{array}{c}-0.356^{* * *} \\
(0.023)\end{array}$ \\
\hline Balochistan & $\begin{array}{c}0.274^{* * *} \\
(0.037)\end{array}$ & $\begin{array}{c}0.276^{* * *} \\
(0.037)\end{array}$ & $\begin{array}{c}0.270^{* * *} \\
(0.034)\end{array}$ \\
\hline \multicolumn{4}{|l|}{ Region (ref. $=$ rural) } \\
\hline Urban & $\begin{array}{c}0.091^{* * *} \\
(0.015)\end{array}$ & $\begin{array}{c}0.080^{* * *} \\
(0.015)\end{array}$ & $\begin{array}{c}0.080^{* * *} \\
(0.014)\end{array}$ \\
\hline \multicolumn{4}{|l|}{ Job status (ref. = permanent) } \\
\hline Contractual & $\begin{array}{l}0.194^{* *} \\
(0.086)\end{array}$ & $\begin{array}{c}0.196^{* * *} \\
(0.084)\end{array}$ & $\begin{array}{l}0.215^{* *} \\
(0.083)\end{array}$ \\
\hline Without contract & $\begin{array}{c}0.070 \\
(0.064)\end{array}$ & $\begin{array}{c}0.081 \\
(0.064)\end{array}$ & $\begin{array}{c}0.081 \\
(0.064)\end{array}$ \\
\hline \multicolumn{4}{|l|}{ Industry (ref. = manufacturing) } \\
\hline Construction & $\begin{array}{l}0.377^{* *} \\
(0.025)\end{array}$ & $\begin{array}{c}0.318^{* * *} \\
(0.029)\end{array}$ & $\begin{array}{c}0.312^{* * *} \\
(0.030)\end{array}$ \\
\hline \multicolumn{4}{|l|}{$\begin{array}{l}\text { Occupation (ref. }=\text { services and } \\
\text { sales) }\end{array}$} \\
\hline Craft and related trades & $\begin{array}{l}-0.197 \\
(0.132)\end{array}$ & $\begin{array}{c}-0.318^{*} \\
(0.133)\end{array}$ & $\begin{array}{l}-0.116 \\
(0.149)\end{array}$ \\
\hline $\begin{array}{l}\text { Plant and machine operation and } \\
\text { assembly }\end{array}$ & $\begin{array}{l}-0.175 \\
(0.141)\end{array}$ & $\begin{array}{l}-0.291^{*} \\
(0.141)\end{array}$ & $\begin{array}{l}-0.080 \\
(0.161)\end{array}$ \\
\hline Elementary occupations & $\begin{array}{l}-0.514^{* * *} \\
(0.133)\end{array}$ & $\begin{array}{l}-0.591^{* * *} \\
(0.131)\end{array}$ & $\begin{array}{l}-0.326^{* *} \\
(0.168)\end{array}$ \\
\hline Constant & $\begin{array}{l}3.601^{* * *} \\
(0.168)\end{array}$ & $\begin{array}{l}3.631^{* * *} \\
(0.164)\end{array}$ & $\begin{array}{c}3.570 \\
(0.160)\end{array}$ \\
\hline F-statistic & 127.60 & 135.80 & 128.88 \\
\hline Adjusted $\mathrm{R}^{2}$ & 0.220 & 0.222 & 0.222 \\
\hline
\end{tabular}

Note: Robust standard errors given in parentheses. ${ }^{*}=$ significant at $10 \%$ level, ${ }^{* *}=$ significant at $5 \%$ level, ${ }^{* * *}=$ significant at $1 \%$ level

Source: Authors' calculations based on data from the Labor Force Survey for 2012/13. 
The province dummies are included in the regression to capture the wage differential between each province relative to Punjab. Both the province and urban/rural dummies are significant, showing that workers' place of residence has a significant effect on their wages. With respect to the job characteristic variables, the estimates show that contractual jobs pay a significantly higher wage than permanent jobs. The 1-digit industry dummy is used to measure the effect of working in a particular industry and its coefficient shows that workers in construction earn 30-40 percent more than their counterparts in manufacturing.

The injury risk variable is the focus of this study. Its estimated coefficient in model 1 is positive but not statistically different from 0 , while the occupational injury risk variable in model 2 is positive and statistically significant at the 1 percent level. The estimated beta of occupational injury risk in model 2 demonstrates that workers are compensated very poorly for the risk they assume at the workplace. The coefficient of occupational injury risk is 0.023 , indicating that a 1 percent increase in injury risk raises the wage level by 2.3 percent.

The difference between the occupational and industrial injury rates is interesting. While an industry comprises a range of occupations (for instance, manufacturing includes assembly and operation, craft and related trades, services and marketing), which lowers the average risk rate, an occupation consists of a specific task associated with a specific injury rate. This is an important finding because it implies that the occupational injury rate is a better measure of exposure to risk.

The SVI per 100 workers is calculated as follows:

$$
S V I=\beta * \bar{\omega} * 2,000 * 100
$$

$S V I_{1}$ is based on the industrial injury rate and has an insignificant coefficient.

$$
\begin{aligned}
& S V I_{1}=0.006^{*} 43^{*} 2,000^{*} 100 \\
& =\text { PKR 51,600/100 workers/year } \\
& =\text { PKR 43/ worker } / \text { month }^{6}
\end{aligned}
$$

\footnotetext{
${ }^{6}$ At the lower and upper confidence interval levels, the value of $S V I_{1}$ for the industrial injury rate is 42.34 and 44.94 , respectively.
} 
$\mathrm{SVI}_{2}$ is based on the occupational injury rate and has a significant coefficient.

$$
\begin{aligned}
& S V I_{2}=0.023^{*} 43^{*} 2,000^{*} 100 \\
& =\text { PKR 197,800/100 workers } / \text { year } \\
& =\text { PKR 165/worker } / \text { month }^{7}
\end{aligned}
$$

Given that the result for occupational injury risk is significant, we also estimate the impact of the occupational injury rate squared to assess the nonlinear relationship between injury risk and the wage rate. Applying the results of model 3 to an occupational injury rate ranging from 0 to 11.5, the labor market begins to pay a premium after the occupational injury rate crosses 3.5, on average. Our final calculation, $\mathrm{SVI}_{3}$, represents the nonlinear relationship between the occupational injury rate and the wage premium.

In the linear model 2 , the wage depended on $\beta^{*}$ (injury rate) so that $d w / d$ (injury rate) $=\beta$ in the $S V I_{2}$ formula. However, in the nonlinear model 3 , the wage depends on $\beta_{1}{ }^{*}$ (injury rate) $+\beta_{2}{ }^{*}$ (injury rate squared), such that $d w / d$ (injury rate) $=\beta_{1}+2 \beta_{2}{ }^{*}$ (injury rate) is the new $\beta$. Since this $\beta$ is no longer constant, we evaluate it at the average occupational injury rate and then apply the SVI formula to determine $\mathrm{SVI}_{3}$ :

$$
\begin{aligned}
& \left.\mathrm{SVI}_{3}=\left[-(0.043)+2(0.006)^{*} \text { (average injury rate }\right)\right]^{*} 43^{*} 2,000^{*} 100 \\
& =\left[-(0.043)+2(0.006)^{*}(5.93)\right]^{*} 43^{*} 2,000^{*} 100 \\
& =0.0281^{*} 43^{*} 2,000^{*} 100 \\
& =\text { PKR } 242,176 / 100 \text { workers } / \text { year } \\
& =\text { PKR 201/ worker } / \text { month }^{8}
\end{aligned}
$$

These figures show that blue-collar workers in Pakistan are paid a relatively small compensating wage differential. High unemployment and the abundance of labor, which gives workers a weaker bargaining position, is a likely contributor to this small differential. Our results are consistent with Elia et al. (2009), where unemployment, job scarcity and

\footnotetext{
${ }^{7}$ At the lower and upper confidence interval levels, the value of $S V I_{2}$ for the occupational injury rate is 161.30 and 172.27 , respectively.

${ }^{8}$ At the lower and upper confidence interval levels, the value of $S V I_{3}$ for the occupational injury rate is 195.0 and 206.9 , respectively.
} 
labor abundance explain the absence of an adequate wage premium for risky jobs.

Our results highlight the inadequacies of labor market institutions and the weak bargaining position of workers in Pakistan, which, when combined with the large supply of labor, open up further opportunities for labor exploitation. Another important implication of these estimates is that the occupational injury rate is a more meaningful indicator of risk than the industrial injury rate.

\section{Conclusion}

This study draws on a sample of blue-collar workers in construction and manufacturing to estimate the SVI for Pakistan's labor market. The industries and occupations selected account for the highest number of injuries in a one-year period relative to other occupations and industries, implying that workers in these sectors are exposed to greater risk of injury. Workers in construction earn more than their counterparts in manufacturing.

The estimates we obtain do not validate the theory of compensating wage differentials to a satisfactory degree: these differentials are negligible and insufficient to cover the cost of damaged health among workers. One possible explanation is that, given Pakistan's high unemployment rate (above 6 percent), people are more willing to accept riskier jobs even if they are not compensated fully for the risk they assume. These results indicate that the area needs further research. 


\section{References}

Atkinson, S. E., \& Halvorsen, R. (1990). The valuation of risks to life: Evidence from the market for automobiles. Review of Economics and Statistics, 72(1), 133-136.

Blomquist, G. C. (2004). Self-protection and averting behavior, values of statistical lives and benefit cost analysis of environmental policy. Review of Economics of the Household, 2(1), 89-110.

Elia, L., Carrieri, V., \& Di Porto, E. (2009). Do you think your risk is fair paid? Evidence from Italian labor market (Working Paper No. 89). Turin: LABOR (Center for Employment Studies).

Halvorsen, R., \& Palmquist, R. (1980). The interpretation of dummy variables in semilogarithmic equations. American Economic Review, $70(3), 474-475$.

Hammitt, J. K., \& Ibarrarán, M. E. (2006). The economic value of fatal and non-fatal occupational risks in Mexico City using actuarial- and perceived-risk estimates. Health Economics, 15(12), 1329-1335.

Hersch, J. (1998). Compensating differentials for gender-specific job injury risk. American Economic Review, 88(3), 598-607.

Hyder, A., \& Behrman, J. R. (2011). Schooling is associated not only with long-run wages, but also with wage risks and disability risks: The Pakistani experience. Pakistan Development Review, 50(4), 555-573.

Kluve, J., \& Schaffner, S. (2007). Gender wage differentials and the occupational injury risk: Evidence from Germany and the US (Ruhr Economic Paper No. 28). Duisburg: University of Duisburg-Essen.

Krueger, A. B., \& Summers, L. H. (1988). Efficiency wages and the interindustry wage structure. Econometrica, 56(2), 259-293.

Liu, J.-T., \& Hammitt, J. K. (1999). Perceived risk and value of workplace safety in a developing country. Journal of Risk Research, 2(3), 263-275.

Madheswaran, S. (2004). Measuring the value of life and limb: Estimating compensating wage differentials among workers in Chennai and Mumbai (Working Paper No. 9-04). Kathmandu: South Asian Network for Development and Environmental Economics. 
Marin, A., \& Psacharopoulos, G. (1982). The reward for risk in the labor market: Evidence from the United Kingdom and a reconciliation with other studies. Journal of Political Economy, 90(4), 827-853.

Nakata, A., Ikeda, T., Takahashi, M., Haratani, T., ... Araki, S. (2006). Impact of psychosocial job stress on non-fatal occupational injuries in small and medium-sized manufacturing enterprises. American Journal of Industrial Medicine, 49(8), 658-669.

Parada-Contzen, M., Riquelme-Won, A., \& Vasquez-Lavin, F. (2013). The value of a statistical life in Chile. Empirical Economics, 45(3), 10731087.

Polat, S. (2013). Wage compensation for risk: The case of Turkey (GIAM Working Paper No. 13-11). Istanbul: Galatasaray University, Economic Research Center.

Rafiq, M., \& Shah, M. K. (2010). The value of reduced risk of injury and deaths in Pakistan - using actual and perceived risk estimates. Pakistan Development Review, 49(4), 823-827.

Schelling, T. C. (1968). The life you save may be your own. In S. B. Chase (Ed.), Problems in public expenditure analysis (pp. 127-162). Washington, DC: Brookings Institution.

Shanmugam, K. R. (2000). Valuations of life and injury risks. Environmental and Resource Economics, 16(4), 379-389.

Thaler, R., \& Rosen, S. (1976). The value of saving a life: Evidence from the labor market. In N. E. Terleckyj (Ed.), Household production and consumption. New York: National Bureau of Economic Research.

United Nations Population Fund. (2013). The state of world population 2013: Motherhood in childhood. New York: Author.

Viscusi, W. K. (2003). The value of life: Estimates with risks by occupation and industry (Discussion Paper No. 422). Cambridge, MA: Harvard Law School, John M. Olin Center for Law, Economics and Business.

Viscusi, W. K., \& Aldy, J. E. (2003). The value of a statistical life: A critical review of market estimates throughout the world (Working Paper No. 9487). Cambridge, MA: National Bureau of Economic Research.

World Bank. (2014). Pakistan: Country partnership strategy for the period FY2015-19. Washington, DC: Author. 


\section{Appendix}

\section{Table A1: Summary of literature review}

\begin{tabular}{|c|c|c|c|c|}
\hline Study & Country & Data source & Methodology & Outcome \\
\hline $\begin{array}{l}\text { Krueger and } \\
\text { Summers (1988) }\end{array}$ & US & $\begin{array}{l}\text { US Census } \\
\text { Bureau } 1974 \text { and } \\
\text { 1979, population } \\
\text { survey for } 1984\end{array}$ & $\begin{array}{l}\text { Standard } \\
\text { deviations }\end{array}$ & $\begin{array}{l}\text { The industry wage } \\
\text { structure is } \\
\text { remarkably stable } \\
\text { across regions and } \\
\text { time, but a detailed } \\
\text { micro-analysis shows } \\
\text { slight wage } \\
\text { differentials based on } \\
\text { the characteristics of } \\
\text { the work performed. }\end{array}$ \\
\hline Viscusi (2003) & US & $\begin{array}{l}\text { Bureau of Labor } \\
\text { Statistics 1992-97 }\end{array}$ & $\begin{array}{l}\text { Hedonic wage } \\
\text { equation, OLS }\end{array}$ & $\begin{array}{l}\text { Blue-collar women } \\
\text { have higher } \\
\text { compensating wage } \\
\text { differentials than } \\
\text { blue-collar men. }\end{array}$ \\
\hline $\begin{array}{l}\text { Viscusi and } \\
\text { Aldy (2003) }\end{array}$ & US & $\begin{array}{l}\text { Bureau of Labor } \\
\text { Statistics }\end{array}$ & $\begin{array}{l}\text { Hedonic wage } \\
\text { equation, OLS }\end{array}$ & $\begin{array}{l}\text { Nonunion members } \\
\text { have lower risk } \\
\text { premiums. VSL } \\
\text { decreases with age. }\end{array}$ \\
\hline $\begin{array}{l}\text { Kluve and } \\
\text { Schaffner (2007) }\end{array}$ & $\begin{array}{l}\text { Germany } \\
\text { and the } \\
\text { US }\end{array}$ & $\begin{array}{l}\text { German } \\
\text { Socioeconomic } \\
\text { Panel, Panel } \\
\text { Study of Income } \\
\text { Dynamics }\end{array}$ & $\begin{array}{l}\text { Hedonic wage } \\
\text { equation, OLS }\end{array}$ & $\begin{array}{l}\text { Men are exposed to } \\
\text { riskier, more } \\
\text { dangerous work than } \\
\text { women. }\end{array}$ \\
\hline Polat (2013) & Turkey & $\begin{array}{l}\text { Ministry of Labor } \\
\text { and Social } \\
\text { Security, } \\
\text { Household Labor } \\
\text { Force Survey } \\
\text { 2010-11 }\end{array}$ & $\begin{array}{l}\text { Hedonic wage } \\
\text { model, OLS }\end{array}$ & $\begin{array}{l}\text { The injury risk } \\
\text { premium is pertinent } \\
\text { in all sectors. In the } \\
\text { case of fatal risk, it is } \\
\text { limited to } \\
\text { manufacturing. }\end{array}$ \\
\hline $\begin{array}{l}\text { Nakata et al. } \\
(2006)\end{array}$ & Japan & Survey & $\begin{array}{l}\text { Multivariable } \\
\text { logistic } \\
\text { regression }\end{array}$ & $\begin{array}{l}\text { There is an expected } \\
\text { increase in the risk of } \\
\text { occupational injury } \\
\text { among current and } \\
\text { former male smokers } \\
\text { and a risk factor for } \\
\text { nonsmokers through } \\
\text { passive smoking. }\end{array}$ \\
\hline Hersch (1998) & US & $\begin{array}{l}\text { Bureau of Labor } \\
\text { Statistics }\end{array}$ & $\begin{array}{l}\text { Hedonic wage } \\
\text { equation, OLS }\end{array}$ & $\begin{array}{l}\text { Adjusting for the } \\
\text { number of women in } \\
\text { employment, they } \\
\text { are } 71 \text { percent as } \\
\text { likely as men to get } \\
\text { injured. }\end{array}$ \\
\hline
\end{tabular}




\begin{tabular}{|c|c|c|c|c|}
\hline Study & Country & Data source & Methodology & Outcome \\
\hline $\begin{array}{l}\text { Elia, Carrieri } \\
\text { and Di Porto } \\
(2009)\end{array}$ & Italy & $\begin{array}{l}\text { Survey of } \\
\text { Household } \\
\text { Income and } \\
\text { Wealth }\end{array}$ & $\begin{array}{l}\text { Hedonic wage } \\
\text { equation, OLS }\end{array}$ & $\begin{array}{l}\text { Small firms pay their } \\
\text { workers a flat wage } \\
\text { risk premium. The } \\
\text { wage-risk tradeoff } \\
\text { does not always } \\
\text { emerge as hedonic } \\
\text { wage theory would } \\
\text { predict. }\end{array}$ \\
\hline $\begin{array}{l}\text { Marin and } \\
\text { Psacharopoulos } \\
\text { (1982) }\end{array}$ & UK & $\begin{array}{l}\text { Office of } \\
\text { Population } \\
\text { Censuses and } \\
\text { Surveys }\end{array}$ & $\begin{array}{l}\text { Hedonic wage } \\
\text { model, OLS, } \\
\text { semi-log linear } \\
\text { model }\end{array}$ & $\begin{array}{l}\text { Workers are } \\
\text { compensated for risk } \\
\text { even if they are not } \\
\text { union members. }\end{array}$ \\
\hline $\begin{array}{l}\text { Shanmugam } \\
(2000)\end{array}$ & India & Survey 1990 & $\begin{array}{l}\text { Hedonic wage } \\
\text { equation, OLS }\end{array}$ & $\begin{array}{l}\text { Minor compensating } \\
\text { wage differentials } \\
\text { exist. }\end{array}$ \\
\hline $\begin{array}{l}\text { Madheswaran } \\
\text { (2004) }\end{array}$ & India & $\begin{array}{l}\text { Survey and } \\
\text { interviews }\end{array}$ & $\begin{array}{l}\text { Hedonic wage } \\
\text { equation, OLS }\end{array}$ & $\begin{array}{l}\text { The labor market } \\
\text { pays INR240 as an } \\
\text { annual wage } \\
\text { premium for risky } \\
\text { jobs. }\end{array}$ \\
\hline $\begin{array}{l}\text { Hammitt and } \\
\text { Ibarrarán (2006) }\end{array}$ & Mexico & Survey & $\begin{array}{l}\text { Hedonic wage } \\
\text { regression, } \\
\text { OLS }\end{array}$ & $\begin{array}{l}\text { The SVI is smaller } \\
\text { than in the US, but } \\
\text { almost the same } \\
\text { when compared to } \\
\text { Taiwan and South } \\
\text { Korea. }\end{array}$ \\
\hline $\begin{array}{l}\text { Liu and } \\
\text { Hammitt (1999) }\end{array}$ & Taiwan & $\begin{array}{l}\text { Survey and } \\
\text { interviews, } \\
\text { Chilean Safety } \\
\text { Association }\end{array}$ & $\begin{array}{l}\text { Hedonic wage } \\
\text { function, OLS }\end{array}$ & $\begin{array}{l}\text { Petrochemical } \\
\text { workers receive a } \\
\text { significant } \\
\text { compensating wage } \\
\text { differential for risky } \\
\text { jobs. }\end{array}$ \\
\hline $\begin{array}{l}\text { Parada- } \\
\text { Contzen, } \\
\text { Riquelme-Won } \\
\text { and Vasquez- } \\
\text { Lavin (2013) }\end{array}$ & Chile & $\begin{array}{l}\text { Chilean Safety } \\
\text { Association }\end{array}$ & $\begin{array}{l}\text { Hedonic wage } \\
\text { model, OLS, } \\
\text { probit model }\end{array}$ & $\begin{array}{l}\text { A wage premium } \\
\text { exists. The results are } \\
\text { consistent with other } \\
\text { developing countries. }\end{array}$ \\
\hline $\begin{array}{l}\text { Rafiq and Shah } \\
(2010)\end{array}$ & Pakistan & $\begin{array}{l}\text { Punjab } \\
\text { Employees Social } \\
\text { Security Institute } \\
\text { (only for Lahore }\end{array}$ & $\begin{array}{l}\text { Hedonic wage } \\
\text { model, OLS }\end{array}$ & $\begin{array}{l}\text { Workers are } \\
\text { compensated for risk } \\
\text { in selected private } \\
\text { sector firms in } \\
\text { Lahore. }\end{array}$ \\
\hline
\end{tabular}


Table A2: Classification of 2-digit level industries

\begin{tabular}{|c|c|}
\hline Code & Industry \\
\hline & Manufacturing \\
\hline 10 & Manufacture of food products \\
\hline 11 & Manufacture of beverages \\
\hline 12 & Manufacture of tobacco products \\
\hline 13 & Manufacture of textiles \\
\hline 14 & Manufacture of wearing apparel \\
\hline 15 & Manufacture of leather and related \\
\hline 16 & $\begin{array}{l}\text { Manufacture of wood and its products and cork manufacture of articles of } \\
\text { straw and plaiting materials }\end{array}$ \\
\hline 17 & Manufacture of paper and paper products \\
\hline 18 & Printing and reproduction of recorded media \\
\hline 19 & Manufacture of coke and refined petroleum products \\
\hline 20 & Manufacture of chemicals and chemical products \\
\hline 21 & $\begin{array}{l}\text { Manufacture of basic pharmaceutical products and pharmaceutical } \\
\text { preparations }\end{array}$ \\
\hline 22 & Manufacture of rubber and plastics \\
\hline 23 & Manufacture of other nonmetallic mineral products \\
\hline 24 & Manufacture of basic metals \\
\hline 25 & Manufacture of fabricated metal products, except machinery and equipment \\
\hline 26 & Manufacture of computer, electronic and optical products \\
\hline 27 & Manufacture of electrical equipment \\
\hline 28 & Manufacture of machinery and equipment \\
\hline 29 & Manufacture of motor vehicles, trailers and semi-trailers \\
\hline 30 & Manufacture of other transport equipment \\
\hline 31 & Manufacture of furniture \\
\hline 32 & Other manufacturing \\
\hline \multirow[t]{2}{*}{33} & Repair and installation of machinery \\
\hline & Construction \\
\hline 41 & Construction of buildings \\
\hline 42 & Civil engineering \\
\hline 43 & Specialized construction activities \\
\hline
\end{tabular}

Source: Pakistan Standard Industrial Classification (all economic activities) Rev. 4 (2010). 


\section{Table A3: Classification of blue-collar occupations}

\begin{tabular}{ll}
\hline Occupation & \multicolumn{1}{c}{ Sub-occupation } \\
\hline Services shop and market sales & $\begin{array}{l}\text { Personal and protective services } \\
\text { Models, sales and demonstrations } \\
\text { Extraction and building trades } \\
\text { Metal, machinery and related trades } \\
\text { Precision, handicraft, printing and related trades } \\
\text { Other craft and related trades } \\
\text { Stationary plant and related operation }\end{array}$ \\
$\begin{array}{l}\text { Plant and machinery operation } \\
\text { and assembly }\end{array}$ & $\begin{array}{l}\text { Machinery operation and assembly } \\
\text { Driving and mobile plant operation } \\
\text { Sales and services elementary occupations } \\
\text { Elementary occupations }\end{array}$ \\
& Labor in mining \\
\hline
\end{tabular}

